\title{
Climate affects food availability to planktivorous least auklets Aethia pusilla through physical processes in the southeastern Bering Sea
}

\author{
I. Dorresteijn ${ }^{1, *}$, A. S. Kitaysky ${ }^{1}$, C. Barger $^{1}$, Z. M. Benowitz-Fredericks ${ }^{1,3}$, \\ G. V. Byrd ${ }^{2}$, M. Shultz ${ }^{1}$, R. Young ${ }^{1}$ \\ ${ }^{1}$ Department of Biology and Wildlife, Institute of Arctic Biology, University of Alaska Fairbanks, Fairbanks, Alaska 99775, USA \\ ${ }^{2}$ Alaska Maritime National Wildlife Refuge, US Fish and Wildlife Service, Homer, Alaska 99603, USA \\ ${ }^{3}$ Biology Department, Bucknell University, Lewisburg, Pennsylvania 17837, USA
}

\begin{abstract}
Climate change might affect marine top predators by altering availability and nutritional quality of their prey. Climate effects vary on a regional basis, and our understanding of the relationships between fluctuations in climate and food resources in sub-arctic regions with seasonal ice cover is limited. We studied the effects of inter-annual climate variability (as reflected in the Pacific Decadal Oscillation, PDO, and the timing of the winter ice retreat) on zooplanktonplanktivorous predator linkages in one of the most productive regions of the southeastern Bering Sea, the 'Green Belt'. We examined changes in diets (species composition of chick meals and stable isotope signatures of adult blood) and relative food availability (as reflected in blood plasma concentrations of the stress hormone corticosterone) of planktivorous least auklets Aethia pusilla breeding on St. George I. (shelf-break) and St. Paul I. (shelf) during 2003 to 2005 and 2008 to 2009. We found that isotopic signatures of blood and composition of chick meals differed between the colonies. The proportion of energy-rich oceanic copepods Neocalanus spp. in the diet declined during warm years (high PDO and early ice retreat) on St. Paul but not on St. George. However, inter-annual and seasonal dynamics of corticosterone were similar between the colonies, and auklets experienced higher nutritional stress during warm compared to cold years. Our results suggest that the influx of prey-bearing water masses from the ocean basin and the retention time of oceanic copepods on the shelf are the main factors affecting composition of prey and its availability to auklets. We conclude that anticipated climate warming will negatively affect food availability of planktivorous predators in the Green Belt region of the southeastern Bering Sea.
\end{abstract}

KEY WORDS: Climate impacts · Nutritional stress • Oceanic shelf-system • Seabirds • Stable isotopes $\cdot$ Corticosterone

\section{INTRODUCTION}

Understanding the impacts of climate change on biota is a major current challenge in ecology and conservation. In marine ecosystems, climate warming affects trophic linkages between producers and primary consumers (Mackas et al. 2007, Ji et al. 2010, Coyle et al. 2011), which in turn alter availability of food re- sources to top predators (Hunt et al. 2002). During reproduction, marine predators such as seabirds rely on predictable seasonal peaks in the availability of prey to meet their energy demands (e.g. Hipfner 2008, Shultz et al. 2009). Climate-induced environmental changes may influence the timing and magnitude of these peaks (Mackas et al. 2007, Hunt et al. 2008). However, specific effects of environmental changes 
on seabirds vary across regions (Irons et al. 2008). In particular, the mechanisms underlying physical forcing are thought to be fundamentally different in marine ecosystems with seasonal ice cover (Hunt et al. 2008). Yet there is a lack of general predictions regarding the impacts of climate on top predators breeding in regions with seasonal ice cover (but see Kitaysky \& Golubova 2000).

Predictions about consequences of anticipated climate warming on the Bering Sea food web have been advanced in the mechanistic Oscillating Control Hypothesis (OCH) (Hunt et al. 2008). The $\mathrm{OCH}$ predicts that regulation of the Bering Sea shelf ecosystem is different between cold and warm climate regimes with a close coupling of zooplankton productivity to the timing of winter ice retreat. Cold regimes with late ice retreat and low water temperatures favor an early phytoplankton bloom and higher probability of secondary blooms (if there is sufficient mixing) in the middle shelf domain, which can sustain a strong production of energy-rich large shelf copepods Calanus marshallae. In contrast, warm regimes with early ice retreat and high water temperatures result in a late phytoplankton bloom and increased stratification of the water column that prevents mixing later in the season and cannot sustain larger species of zooplankton (Hunt et al. 2008, 2011). These predictions have been generally supported by field observations made in the middle shelf domain regions of the Bering Sea (Baier \& Napp 2003, Coyle et al. 2008, 2011), but the implications for top predators have not been directly investigated.

The Green Belt (see Fig. 1) is a vast region and one of the most productive areas of the Bering Sea (Springer et al. 1996). The Green Belt is characterized by large influx of oceanic water masses into a (seasonally ice covered) shelf ecosystem (Springer et al. 1996). Thus the Green Belt is a more heterogeneous environment than the ocean basin and middle shelf domains situated farther away from the shelf edge, with zooplankton communities originating from both the ocean basin and the shelf (Coyle et al. 2008, Stabeno et al. 2008). The $\mathrm{OCH}$ does not address potential effects of the influx of oceanic water masses and energy-rich oceanic copepods Neocalanus spp. into the shelf regions (Coyle et al. 2008), and the applicability of the $\mathrm{OCH}$ to food web structuring in the Green Belt regions has not been previously tested.

Seabirds integrate processes at low trophic levels and changes in their food availability indicate potential changes in prey communities and abundances (e.g. Furness \& Camphuysen 1997, Piatt et al. 2007). In the Bering Sea, planktivorous auklets have been used as indicators of environmental variability and ecosystem response to physical forcing (Springer \& Roseneau 1985, Springer et al. 2007, BenowitzFredericks et al. 2008, Bond et al. 2011). Least auklets preferentially feed on large energy-rich calanoid copepods originating either from the ocean basin (Neocalanus cristatus, N. plumchrus and N. flemingeri) or from the shelf (Calanus marshallae), which they replace with lower-quality prey such as euphausiids, decapods and amphipods when copepods are scarce (Bédard 1969, Springer \& Roseneau 1985, Roby \& Brink 1986, Springer et al. 2007).

We assessed inter-annual and seasonal changes in environmental conditions on the availability of food to least auklets Aethia pusilla, one of the most numerous planktivorous seabirds breeding in the Pribilof Domain, which is located in the southeastern part of the Green Belt. We used a 2-pronged approach to examine the effects of climate variability on food resources of least auklets breeding on the 2 largest colonies of St. Paul I. (continental shelf region) and St.

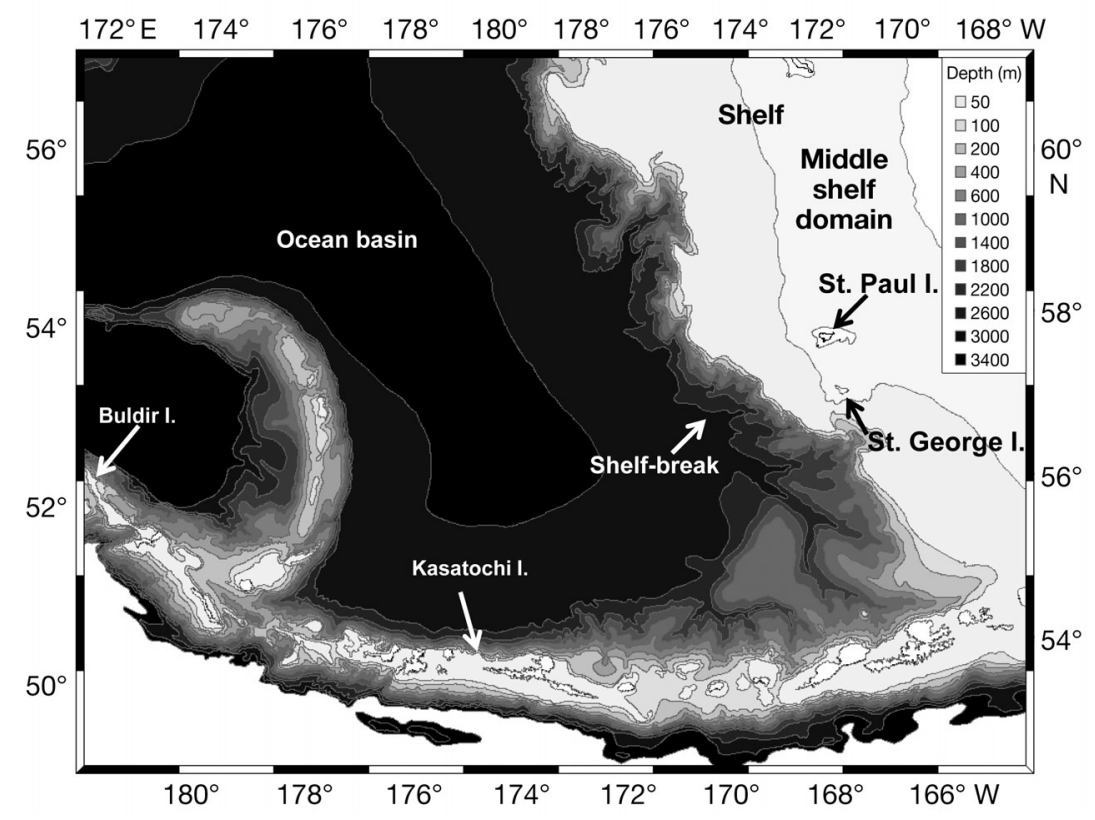

Fig. 1. Southeastern Bering Sea showing the location of the Pribilof Islands, St. Paul I. (shelf) and St. George I. (shelf-break), and the Aleutian Islands, Buldir I. and Kasatochi I. (ocean basin). The Green Belt runs along the edge of the continental shelf (shelf-break). For a detailed description on the location of the Green Belt and the major currents see Springer et al. (1996; their Figs. 1 \& 2) 
George I. (shelf-break region), Pribilof Islands (Fig. 1). First, we used species composition of chick meals and stable isotope signatures in red blood cells of adults to characterize the type of prey species and its origin (relative distance from shelf), respectively. Interannual changes in diet composition are suggested to be indicative of climate-driven phenological mismatches between prey and seabirds (Springer et al. 2007, Hipfner 2008), and stable isotope signatures of carbon $\left(\delta^{13} \mathrm{C}\right)$ of birds' tissues are frequently used to assess the origin of the prey (i.e. Quillfeldt et al. 2005). $\delta^{13} \mathrm{C}$ signatures decline along the continental shelf-ocean basin gradient (Hobson et al. 1994) and hence can be used to distinguish between foraging locations in the shelf and oceanic regions of the Bering Sea (Schell et al. 1998, Smith et al. 2002). Second, since direct quantification of temporal changes in food availability in marine ecosystems is often logistically impossible, we used blood plasma levels of the stress hormone corticosterone in adults as a proxy for changes in their food availability (Kitaysky et al. 2007, 2010, Benowitz-Fredericks et al. 2008). Concentrations of this hormone increases predictably in response to declines in food availability (Kitaysky et al. 1999a,b, 2001, 2007, Wingfield \& Kitaysky 2002). This technique has been successfully applied in ecological studies of several species of seabirds (Buck et al. 2007, Williams et al. 2007, Doody et al. 2008, Welcker et al. 2009), including least auklets (BenowitzFredericks et al. 2008).

The goals of the present study were (1) to examine foraging responses to inter-annual climate variability of planktivorous seabirds breeding at locations with different oceanographic properties in the Green Belt of the southeastern Bering Sea; and (2) to understand the underlying mechanism(s) driving climate-induced variations in food availability to planktivores at the Green Belt. The specific objective was to compare the inter-annual and seasonal dynamics of species compositions and stable isotope values of diets and corticosterone levels of breeding least auklets in 2 locations between the relatively warm years of 2003 to 2005 and the cold years of 2008 to 2009. Based on the $\mathrm{OCH}$ and previous studies in the southeastern Bering Sea (Hunt et al. 2002, 2008, Springer et al. 2007, Benowitz-Fredericks et al. 2008, Coyle et al. 2008, Stabeno et al. 2008), we made the following predictions: (1) Diet composition differs between birds breeding on St. Paul I. and St. George I., with the diet composition of birds on St. George I. containing a larger proportion of oceanic prey. This difference should be most strongly pronounced during warm years when oceanic copepods are scarce in the shelf regions (Coyle et al. 2008). (2) Stable isotope signatures of $\delta^{13} \mathrm{C}$ should be higher in birds breeding on St. Paul I. compared to birds breeding on St. George I., reflecting the colony's proximity to the shelf-break. We expect the difference in $\delta^{13} \mathrm{C}$ between the islands to be larger during warm years, when birds breeding on St. Paul I. do not have access to oceanic Neocalanus copepods, compared to cold years when oceanic copepods are present in the diet of birds on both islands (Springer et al. 2007). (3) Levels of corticosterone should be higher during warm years when food availability is low. We expect the inter-annual and seasonal dynamics of corticosterone to be similar between islands (BenowitzFredericks et al. 2008) since climate-induced changes in physical forcing have been observed to affect the entire region (Stabeno et al. 2008).

\section{MATERIALS AND METHODS}

\section{Study site and climate variables}

The study was conducted at the 2 major Pribilof Islands, St. George I. $\left(56^{\circ} 36^{\prime} 20^{\prime \prime} \mathrm{N}, 1^{\circ} 39^{\circ} 33^{\prime} 35^{\prime \prime} \mathrm{W}\right.$, located near the shelf-break, and St. Paul I. $\left(57^{\circ} 7^{\prime} 30^{\prime \prime} \mathrm{N}, 170^{\circ} 17^{\prime} 3^{\prime \prime} \mathrm{W}\right)$, located on the continental shelf in the southeastern Bering Sea (Fig. 1), during the relatively warm years 2003 to 2005 and the cold years 2008 to 2009. St. Paul and St. George Islands are situated approx. $90 \mathrm{~km}$ from each other and are located in the Pribilof Domain.

Inter-annual climate variability was characterized by the Pacific Decadal Oscillation (PDO) and by the Ice Retreat Indices (IRI) (Table 1). We chose these pa-

Table 1. Climate variables. The Pacific Decadal Oscillation (PDO) index is the leading principal component of the monthly North Pacific sea surface temperature variability. The summer PDO is the average PDO from June, July and August. In the eastern Bering Sea, positive PDO values correspond to warm conditions, whereas negative values correspond to cold conditions. The Ice Retreat Index (IRI) is defined as the number of days after March 15 when the average ice concentration is more than $10 \%$ of a specified area on the continental shelf of the eastern Bering Sea (www.beringclimate.noaa.gov/data)

\begin{tabular}{|ccc|}
\hline Year & Summer PDO & IRI \\
\hline 2003 & 0.84 & 0 \\
2004 & 0.44 & 23 \\
2005 & 0.69 & 0 \\
2008 & -1.57 & 35 \\
2009 & -0.25 & 46 \\
\hline
\end{tabular}


rameters based on the mechanistic predictions of the $\mathrm{OCH}$, which focuses on the roles of timing of ice retreat and summer water temperatures in regulation of zooplankton productivity (Hunt et al. 2008). The PDO index is the leading principal component of the monthly North Pacific sea surface temperature variability (Mantua et al. 1997). In the eastern Bering Sea, positive PDO values correspond to warm conditions, whereas negative values correspond with cold conditions. The summer PDO is the average PDO from June, July and August. The IRI is defined as the number of days after March 15 when the average ice concentration is more than $10 \%$ of a specified area on the continental shelf of the eastern Bering Sea (for more details see www.beringclimate.noaa.gov/data).

\section{Capture and blood sampling of study species}

We studied least auklets during the breeding season from June to August each year. Least auklets incubate for approx. $30 \mathrm{~d}$ followed by a chick-rearing period of about 26 to 31 d (Roby \& Brink 1986), and both sexes share parental duties equally (Jones 1993). During 2003 to 2005, our aim was to sample 10 birds during 3 breeding stages: incubation (2 June to 21 June), early chick-rearing (28 June to 15 July), and late chick-rearing (26 July to 2 Aug). In 2008 and 2009, we sampled 10 birds every week on St. Paul I. and every second week on St. George I. starting in early July until mid-August. In 2008, due to extensive snow cover at the colonies, egg-laying was delayed (Konyukhov 2008), which allowed us to sample chick-rearing adults later in the season compared to previous years. We also collected blood from auklets nesting at 2 Aleutian Islands, Buldir I. $\left(52^{\circ} 21^{\prime} 17^{\prime \prime} \mathrm{N}\right.$,

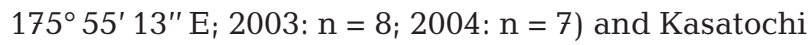
I. (52 $10^{\prime} 39^{\prime \prime} \mathrm{N}, 175^{\circ} 30^{\prime} 30^{\prime \prime} \mathrm{W}$; 2005: $\mathrm{n}=7$ ) (Fig. 1), to characterize isotope values of least auklets foraging only in oceanic water masses.

Auklets were captured at their colonies during daylight hours, using mist nets and noose carpets (Benowitz-Fredericks et al. 2008). Birds were sampled for blood from the brachial vein of the wing using a hypodermic needle and heparinized capillary tubes. All blood samples were taken within $3 \mathrm{~min}$ after capture. Unlike catecholamine hormones, such as adrenaline, which are stored and released into circulation almost immediately in response to a stressor, such as being captured, corticosterone must be synthesized in response to the stressor and is not manifest in the bloodstream for several minutes (reviewed in Sapolsky et al. 2000). Therefore, blood samples obtained within 3 min of initial capture reliably reflect baseline (pre-capture) levels in birds (reviewed in Romero \& Reed 2005). Blood samples were stored on ice and centrifuged on the same day to separate plasma from red blood cells. After separation, plasma and red blood cells (RBC) were frozen until corticosterone and stable isotope analyses. Least auklets provision their chick by delivering whole zooplankton prey items that they store in a gular pouch (Bédard 1969). Auklets voluntarily regurgitate chick meals upon capture, and those were collected and stored in a preservative until further analyses. Active breeding was verified by the presence of chick meals in a gular pouch and/or brood patch status. An overview of sample sizes is given in Table 2 .

\section{Identification of prey}

Chick meals were analyzed for prey species composition by identifying individual specimens to the lowest taxonomic level possible. Morphological similarities prevented us from distinguishing between the 2 closely-related species Neoclananus plumchrus and $N$. flemingeri, and the data for those 2 species were pooled for analyses. Following Springer \& Roseneau (1985) and Springer et al. (2007), we calculated the percentage biomass for each category. Since we were interested in the proportion of copepods in the diets and the location from which they originated, we divided the diet contents into 3 major categories: oceanic Neocalanus copepods (N. cristatus and N. plumchrus/flemingeri), shelf copepods (Calanus marshallae), and other zooplankton originating mainly from the shelf.

\section{Stable isotope analyses}

Turnover time of isotopes in the tissue is critical when using stable isotopes as dietary tracers since it determines whether the isotopes reflect past or current diet (Hobson \& Clark 1992, 1993). We used red blood cells which turn over every 15 to $17 \mathrm{~d}$, so that the carbon they contain came from diets during the previous 2 to $3 \mathrm{wk}$ (Carleton \& del Rio 2005), to gain information about the origin of auklet diet before the onset of sampling, which was especially important for 2008 to 2009 when sampling started at late incubation. Red blood cells were freeze-dried and analyzed with continuous flow isotope ratio mass spectrometry (CF-IRMS) using a Costech Elemental Analyzer (Model ECS 4010), a Thermo Finnigan 
Table 2. Aethia pusilla. Sampling dates and sample sizes for the regurgitations of chick meals, stable isotope values of $\delta^{13} \mathrm{C}$ in red blood cells, and baseline corticosterone levels in the blood plasma of adult least auklets breeding on St. Paul I. (shelf) and St. George I. (shelf-break), Pribilof Islands, in 2003 to 2005 and 2008 to 2009

\begin{tabular}{|c|c|c|c|c|c|c|c|c|}
\hline \multirow[t]{2}{*}{ Year } & \multicolumn{4}{|c|}{ _ St. Paul } & \multicolumn{4}{|c|}{ — St. George _ } \\
\hline & $\begin{array}{l}2 \text { Jun } \\
\text { to } 21 \text { Jun }\end{array}$ & $\begin{array}{l}28 \mathrm{Jun} \\
\text { to } 11 \mathrm{Jul}\end{array}$ & $\begin{array}{l}12 \mathrm{Jul} \\
\text { to } 2 \mathrm{Aug}\end{array}$ & $\begin{array}{l}3 \mathrm{Aug} \\
\text { to } 12 \mathrm{Aug}\end{array}$ & $\begin{array}{l}2 \text { Jun } \\
\text { to 21Jun }\end{array}$ & $\begin{array}{l}28 \mathrm{Jun} \\
\text { to } 11 \mathrm{Jul}\end{array}$ & $\begin{array}{l}12 \mathrm{Jul} \\
\text { to } 2 \mathrm{Aug}\end{array}$ & $\begin{array}{l}3 \mathrm{Aug} \\
\text { to } 12 \mathrm{Aug}\end{array}$ \\
\hline \multicolumn{9}{|c|}{ Chick meals } \\
\hline 2003 & & 13 & 13 & & & 25 & 11 & \\
\hline 2004 & & 60 & 41 & & & 11 & 8 & \\
\hline 2005 & & 31 & 19 & & & & 20 & 27 \\
\hline 2008 & & & 31 & 22 & & & 33 & \\
\hline 2009 & & 1 & 39 & & & & 33 & \\
\hline \multicolumn{9}{|l|}{$\delta^{13} \mathrm{C}$} \\
\hline 2003 & 14 & & 8 & & 7 & 7 & 7 & \\
\hline 2004 & 21 & 20 & 6 & & 7 & 7 & 7 & \\
\hline 2005 & 7 & 7 & 6 & & 7 & 7 & 7 & \\
\hline 2008 & & 7 & 7 & 7 & & 8 & 7 & 5 \\
\hline 2009 & & 10 & 20 & & & 10 & 20 & \\
\hline \multicolumn{9}{|c|}{ Corticosterone } \\
\hline 2003 & 14 & & 12 & & 10 & 24 & 14 & \\
\hline 2004 & 22 & 20 & 7 & & 18 & 20 & 10 & \\
\hline 2005 & 12 & 9 & 6 & & 10 & 20 & 20 & \\
\hline 2008 & & 35 & 32 & 18 & & 11 & 15 & 5 \\
\hline 2009 & & 12 & 39 & & & 10 & 16 & 1 \\
\hline
\end{tabular}

MAT ConFlo III interface and a Delta Plus IRMS, at the Alaska Stable Isotope Facilities of the University of Alaska Fairbanks (Williams et al. 2007). Isotope results are presented in $\delta$ notation according to:

$$
\delta X=\left[\left(R_{\text {sample }} / R_{\text {standard }}-1\right)\right] \times 1000 \%
$$

where $X$ is either ${ }^{15} \mathrm{~N}$ or ${ }^{13} \mathrm{C}$ and $R$ is the ratio of heavy to light isotope $\left({ }^{15} \mathrm{~N} /{ }^{14} \mathrm{~N}\right.$ and $\left.{ }^{13} \mathrm{C} /{ }^{12} \mathrm{C}\right)$. Atmospheric air and Vienna PD belemnite were used as standards for nitrogen and carbon, respectively. Measurement precision (SD) based on replicate measurements of the laboratory standard (peptone) was $\pm 0.11 \%$ for $\delta^{13} \mathrm{C}$.

\section{Corticosterone assay}

Total corticosterone (free and bound fractions) was measured using a radioimmunoassay at the University of Alaska Fairbanks, according to established protocols (Benowitz-Fredericks et al. 2008). Briefly, for each sample, $20 \mu$ of plasma was equilibrated with $2000 \mathrm{cpm}$ of tritiated corticosterone prior to extraction with $4 \mathrm{ml}$ of re-distilled dichloromethane. After extraction, percent tritiated hormone recovered from each individual sample was assessed and used to correct final values. Samples were reconstituted in PBSG buffer and combined with antibody and radiolabel in a radioimmunoassay (Wingfield \& Farner
1975, Wingfield et al. 1991). Dextran-coated charcoal was used to separate antibody-bound hormone from unbound hormone. Inter- and intra-assay CVs were less than $9 \%$ and $2 \%$, respectively.

\section{Statistical analyses}

All data were analyzed using the ' $\mathrm{R}$ ' statistical packages. Data on corticosterone levels were logtransformed to meet the assumptions of normality and heterogeneity of variances for parametric tests (Zar 1999). All inter-annual comparisons were performed on data obtained between July 12 and August 2 during chick-rearing.

To test the relationship between foraging locations and stable isotope values of auklets blood, we examined a change in the isotopic signatures between the ocean basin and the continental shelf regions of the Bering Sea. We compared the isotope values of red blood cells of birds breeding on the 2 Aleutian Islands (Buldir I. and Kasatochi I., ocean basin), with St. George I. (shelf-break) and St. Paul I. (shelf) using 2way ANOVA with Location and Year as fixed factors.

To examine how inter-annual climate variability affects the composition, origin, and availability of prey, we ran a linear model with Island as fixed factor and summer PDO and IRI as continuous predictor 
variables for responses in the proportion of $\mathrm{Neo}$ calanus copepods in the diet, $\delta^{13} \mathrm{C}$, and corticosterone. The interaction terms island by summer PDO and island by IRI were included to test whether the islands respond to climate variability similarly. We only used the percentage oceanic Neocalanus copepods in the diet, since they are the main copepods in auklet diets. Since the data on diet composition were not normally distributed and could not be transformed to meet the requirements of parametric tests, we performed the analyses on ranks. To investigate significant interaction terms, we used correlation analyses (Spearman's rank correlation test for the proportion of Neocalanus in the diet).

For seasonal comparisons of $\delta^{13} \mathrm{C}$ and corticosterone, we were primarily interested in how seasonal changes in response variables were affected by the environmental parameters (IRI and PDO) and between the islands. As our test of homogeneity of slopes indicated significant Year $\times$ Date $\times$ Island interaction terms $\left(\delta^{13} \mathrm{C}: F_{4,245}=2.58, \mathrm{p}=0.038\right.$; corticosterone: $\left.F_{4,406}=5.59, \mathrm{p}<0.001\right)$, the interpretation of results of a full ANCOVA model would be difficult. Thus we conducted separate ANCOVAs with colony as factor and date as covariate for each year, with $\delta^{13} \mathrm{C}$ and corticosterone as response variables. To examine the relationships between colony-year-specific seasonal enrichment of $\delta^{13} \mathrm{C}$ and summer PDO and IRI we used regression analyses.

\section{RESULTS}

\section{Spatial comparisons of stable isotopes}

As expected from the colony locations, stable isotope values of $\delta^{13} \mathrm{C}$ in red blood cells of auklets were low for birds breeding in the ocean basin (Aleutian Islands) compared to birds breeding on the shelf (St. Paul I.); birds breeding close to the shelf-break (St. George I.) had intermediate values (island effect $\delta^{13} \mathrm{C}: F_{2,64}=465.88, \mathrm{p}<0.001$ ) (Fig. 2).

We also observed a large difference in $\delta^{15} \mathrm{~N}$ between birds on the Pribilof Is. and the Aleutian Is. (Fig. 2). Nitrogen stable isotopes provide information about the trophic level of the birds' diet (Hobson et al. 1994); however, interpreting differences in trophic levels is beyond the scope of this study. Therefore, we include the data for comparison to other studies/species, but will not discuss the differences in $\delta^{15} \mathrm{~N}$ signatures, focussing only on differences in $\delta^{13} \mathrm{C}$ signatures that indicate the origin of the prey source.

\section{Inter-annual comparisons}

Diet species composition differed markedly between the islands (Table 3, Fig. 3): while oceanic Neocalanus copepods dominated the diets of auklets on St. George I. (except in 2003), they were entirely absent or occurred in small amounts in the diets of birds on St. Paul I. during 2003 to 2005. There was a significant negative relationship between summer PDO and the proportion of Neocalanus in the diet, but there was no overall effect of IRI (Table 3). However, the effects of summer PDO and IRI on the proportion of Neocalanus in the diet differed between the islands (Table 3). The proportion of Neocalanus copepods in the diet decreased in warmer years only for birds breeding on St. Paul I. (summer PDO, St. Paul: $\mathrm{r}_{\mathrm{S}}=$ $-0.82, \mathrm{p}<0.001$; St. George: $\mathrm{r}_{\mathrm{S}}=-0.11, \mathrm{p}=0.252$, Fig. 3). The proportion of Neocalanus copepods in the diet of least auklets breeding on St. Paul also increased with later timing of ice retreat (IRI: $\mathrm{r}_{\mathrm{S}}=0.75$, $\mathrm{p}<0.001$ ). However, an opposite, albeit weak, trend was observed on St. George, with a decrease in the proportion of Neocalanus copepods in the diet with later timing of ice retreat (IRI: $\mathrm{r}_{\mathrm{S}}=-0.20, \mathrm{p}=0.027$ ).

During the 5 study years, $\delta^{13} \mathrm{C}$ values were consistently higher in birds breeding on St. Paul I. than those on St. George I. (Table 3, Fig. 2). There was no overall relationship between climate variability (as reflected in summer PDO and IRI) and $\delta^{13} \mathrm{C}$ of auklets on the Pribilof Islands. However, the relationship between IRI and $\delta^{13} \mathrm{C}$ was different between the islands (Table 3): a decrease in $\delta^{13} \mathrm{C}$ with later timing of ice

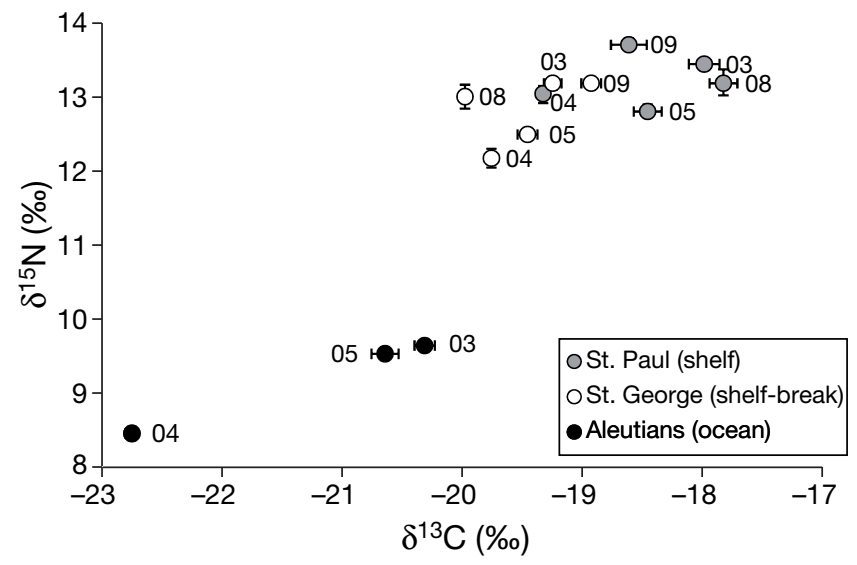

Fig. 2. Aethia pusilla. Inter-annual and inter-island variation in $\delta^{13} \mathrm{C}$ and $\delta^{15} \mathrm{~N}$ signatures (mean $\pm \mathrm{SE}$ ) in red blood cells of least auklets breeding on the Pribilof Islands, St. Paul I. (shelf) and St. George I. (shelf-break), in 2003 to 2005 and 2008 to 2009; and the Aleutian Islands (ocean basin), Buldir I. and Kasatochi I., in 2003 to 2005 . As predicted, $\delta^{13} \mathrm{C}$ signatures were enriched in birds breeding on the shelf compared to birds breeding in the ocean basin and shelf-break 
retreat was observed on St. Paul I. $(\mathrm{r}=-0.27, \mathrm{p}=$ 0.044) whereas an increase was observed on St. George I. ( $\mathrm{r}=-0.31, \mathrm{p}=0.032$ ).

There was no inter-island difference in corticosterone (Table 3, Fig. 3), and there was a significant

Table 3. Aethia pusilla. The effects of the island, Ice Retreat Index (IRI) and summer Pacific Decadal Oscillation (PDO) on average annual proportion of Neocalanus in the diet, baseline corticosterone levels in the blood plasma, and $\delta^{13} \mathrm{C}$ in red blood cells of least auklets breeding on St. Paul I. (shelf) and St. George I. (shelf-break), Pribilof Islands, in 2003 to 2005 and 2008 to 2009. Statistically significant relationships $(\mathrm{p}<0.05)$ are in bold

\begin{tabular}{|c|c|c|c|c|c|}
\hline & $\begin{array}{l}\text { Effect } \\
\text { df }\end{array}$ & $F$ & $\begin{array}{c}\text { Error } \\
\text { df }\end{array}$ & $\mathrm{p}$ & $\begin{array}{c}\text { Parameter estimate } \\
(95 \% \mathrm{CI})\end{array}$ \\
\hline \multicolumn{6}{|l|}{ Neocalanus } \\
\hline Island & 1 & 37.61 & 237 & $<0.001$ & $-132.36(-160.79,-103.93)$ \\
\hline Summer PDO & 1 & 91.24 & 237 & $<0.001$ & $-26.66(-40.35,-12.97)$ \\
\hline IRI & 1 & 0.97 & 237 & 0.326 & $-1.29(-1.95,-0.64)$ \\
\hline $\begin{array}{l}\text { Island } \times \\
\text { Summer PDO }\end{array}$ & 1 & 61.12 & 237 & $<0.001$ & $-20.05(-38.73,-1.37)$ \\
\hline Island $\times$ IRI & 1 & 39.15 & 237 & $<0.001$ & $3.16(2.16,4.15)$ \\
\hline \multicolumn{6}{|l|}{$\delta^{13} \mathrm{C}$} \\
\hline Island & 1 & 89.15 & 99 & $<0.001$ & $2.09(1.67,2.51)$ \\
\hline Summer PDO & 1 & 0.22 & 99 & 0.637 & $0.49(0.23,0.75)$ \\
\hline IRI & 1 & 0.31 & 99 & 0.582 & $0.02(0.01,0.03)$ \\
\hline $\begin{array}{l}\text { Island } \times \\
\text { Summer PDO }\end{array}$ & 1 & 2.13 & 99 & 0.148 & $-1.01(-1.38,-0.64)$ \\
\hline Island $\times$ IRI & 1 & 37.51 & 99 & $<0.001$ & $-0.04(-0.06,-0.03)$ \\
\hline \multicolumn{6}{|l|}{ Corticosterone } \\
\hline Island & 1 & 1.75 & 168 & 0.188 & $0.21(0.04,0.38)$ \\
\hline Summer PDO & 1 & 36.36 & 168 & $<0.001$ & $0.15(0.05,0.25)$ \\
\hline IRI & 1 & $<0.01$ & 168 & 0.994 & $<0.01(<0.01,0.01)$ \\
\hline $\begin{array}{l}\text { Island } \times \\
\text { Summer PDO }\end{array}$ & 1 & 3.53 & 168 & 0.062 & $-0.01(-0.14,0.11)$ \\
\hline Island $\times$ IRI & 1 & 6.38 & 168 & 0.012 & $-0.01(-0.01,<-0.01)$ \\
\hline
\end{tabular}

positive relationship between corticosterone and the summer PDO index (Table 3, Fig. 3), indicating that on both islands, corticosterone levels were higher during years with warmer sea-surface temperatures. There was no overall effect of IRI on corticosterone, but birds breeding on St. Paul I. and St. George I. were affected differently (Table 3). Birds on St. Paul I. had highest corticosterone levels during years with early ice retreat $(\mathrm{r}=-0.44$, $\mathrm{p}<0.001$ ); birds on St. George I. were not affected by ice conditions ( $\mathrm{r}=$ $-0.08, \mathrm{p}=0.485$ ).

\section{Seasonal comparisons}

Seasonal shifts in the diet composition were more pronounced during the warm compared to cold years (Table 4). A shift from calanoid copepods to other zooplankton species in the diet occurred in the warm years during mid-July of 2004 and 2005 on St. Paul I., and in late July of 2003 on St. George I. Oceanic Neocalanus copepods were present in the diets of birds on St. George I. during all years but were only present in the diets of birds on St. Paul I. during years with late ice retreat, and they remained the dominant prey species during the cold years 2008 and 2009 but not in the warm year 2004 .
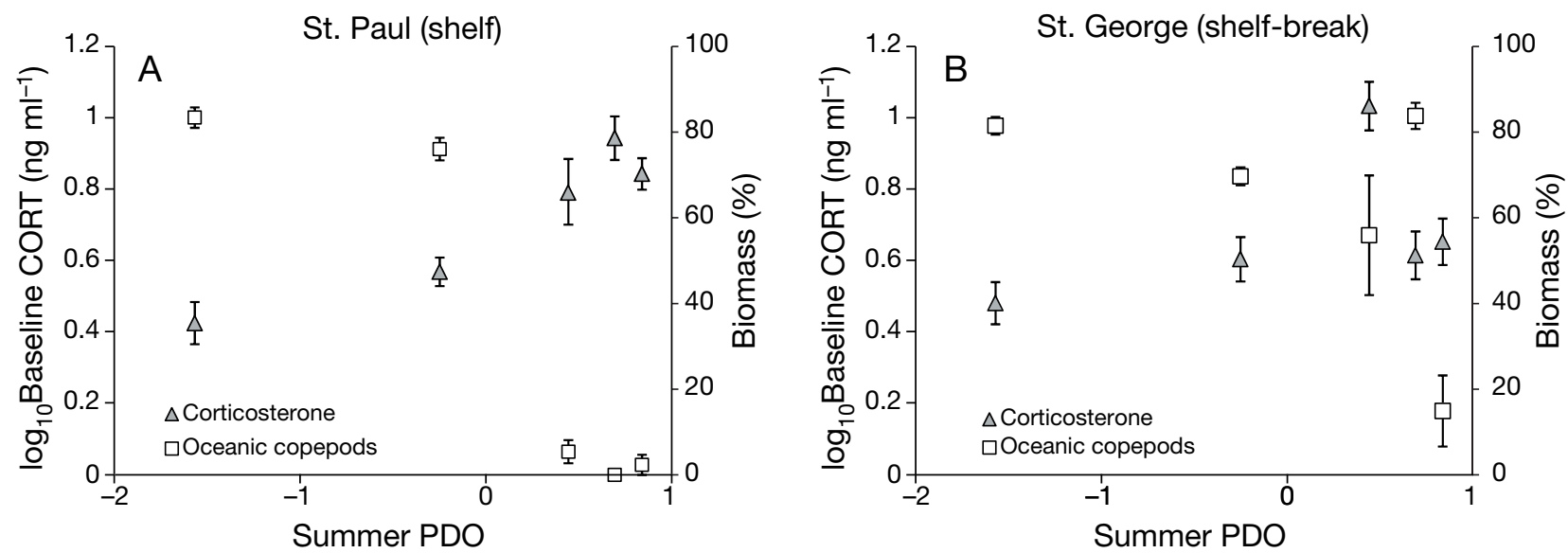

Fig. 3. Aethia pusilla. Relationship between summer Pacific Decadal Oscillation (PDO) and annual baseline corticosterone levels $($ CORT; mean \pm SE) in the blood plasma and the proportion of oceanic copepods Neocalanus spp. (mean \pm SE) in the diets of least auklets breeding on (A) St. Paul I. (shelf) and (B) St. George I. (shelf-break), Pribilof Islands, in 2003 to 2005 and 2008 to 2009. Corticosterone levels were similar between the islands and were higher during warm years (positive PDO) 
Table 4. Aethia pusilla. Percentage biomass (mean \pm SE) of oceanic copepods Neocalanus spp., shelf copepod Calanus marshallae and other zooplankton prey in regurgitated chick meals of least auklets breeding on St. Paul I. (shelf) and St. George I. (shelf-break), Pribilof Islands, in 2003 to 2005 and 2008 to 2009

\begin{tabular}{|c|c|c|c|c|c|c|c|c|c|}
\hline \multirow[t]{2}{*}{ Year } & \multirow{2}{*}{ Species } & \multicolumn{4}{|c|}{ - St. Paul } & \multicolumn{4}{|c|}{ - St. George } \\
\hline & & $\begin{array}{l}29 \mathrm{Jun} \\
\text { to } 10 \mathrm{Jul}\end{array}$ & $\begin{array}{l}11 \mathrm{Jul} \\
\text { to } 18 \mathrm{Jul}\end{array}$ & $\begin{array}{l}19 \mathrm{Jul} \\
\text { to } 27 \mathrm{Jul}\end{array}$ & $\begin{array}{l}28 \mathrm{Jul} \\
\text { to } 12 \mathrm{Aug}\end{array}$ & $\begin{array}{l}29 \mathrm{Jun} \\
\text { to } 10 \mathrm{Jul}\end{array}$ & $\begin{array}{l}11 \mathrm{Jul} \\
\text { to } 18 \mathrm{Jul}\end{array}$ & $\begin{array}{c}19 \mathrm{Jul} \mathrm{Jul} \\
\text { to } 27 \mathrm{Jul}\end{array}$ & $\begin{array}{c}28 \mathrm{Jul} \\
\text { to } 12 \mathrm{Aug}\end{array}$ \\
\hline \multirow[t]{3}{*}{2003} & Oceanic copepods & $10.3 \pm 5.9$ & & $3.4 \pm 3.4$ & 0 & $93.0 \pm 2.0$ & $84.2 \pm 9.6$ & & $14.9 \pm 8.3$ \\
\hline & Shelf copepods & $4.2 \pm 4.0$ & & $0.5 \pm 0.5$ & 0 & 0 & 0 & & $3.7 \pm 3.0$ \\
\hline & Other zooplankton & $85.5 \pm 7.2$ & & $96.1 \pm 3.4$ & 100 & $7.0 \pm 2.0$ & $15.8 \pm 9.6$ & & $81.4 \pm 9.1$ \\
\hline \multirow[t]{3}{*}{2004} & Oceanic copepods & $81.4 \pm 2.2$ & & $6.2 \pm 3.0$ & 0 & $67.7 \pm 6.5$ & & $55.9 \pm 14.0$ & \\
\hline & Shelf copepods & 0 & & $1.8 \pm 1.5$ & 0 & 0 & & 0 & \\
\hline & Other zooplankton & $18.6 \pm 2.2$ & & $92.1 \pm 3.7$ & 100 & $32.3 \pm 6.5$ & & $44.1 \pm 14.0$ & \\
\hline \multirow[t]{3}{*}{2005} & Oceanic copepods & 0 & & 0 & & $84.3 \pm 3.0$ & $88.4 \pm 2.3$ & $76.4 \pm 6.7$ & $89.4 \pm 2.9$ \\
\hline & Shelf copepods & $59.5 \pm 16.0$ & & $0.6 \pm 0.6$ & & $0.4 \pm 0.2$ & 0 & 0 & 0 \\
\hline & Other zooplankton & $40.5 \pm 16.0$ & & $99.4 \pm 0.6$ & & $15.3 \pm 3.0$ & $11.6 \pm 2.3$ & $23.6 \pm 6.7$ & $10.6 \pm 2.9$ \\
\hline \multirow[t]{3}{*}{2008} & Oceanic copepods & & $82.0 \pm 5.3$ & $81.1 \pm 4.5$ & $87.6 \pm 1.6$ & & $84.6 \pm 2.0$ & $72.4 \pm 4.1$ & $88.1 \pm 1.5$ \\
\hline & Shelf copepods & & $3.7 \pm 1.9$ & $4.2 \pm 3.1$ & $3.3 \pm 1.2$ & & $0.6 \pm 0.3$ & $0.3 \pm 0.1$ & $0.4 \pm 0.1$ \\
\hline & Other zooplankton & & $14.2 \pm 3.6$ & $14.6 \pm 2.8$ & $9.2 \pm 1.2$ & & $14.9 \pm 2.0$ & $27.2 \pm 4.1$ & $11.4 \pm 1.5$ \\
\hline \multirow[t]{3}{*}{2009} & Oceanic copepods & & $74.4 \pm 4.2$ & $72.1 \pm 3.6$ & $91.0 \pm 4.0$ & & $68.2 \pm 2.5$ & & $70.9 \pm 3.3$ \\
\hline & Shelf copepods & & $5.3 \pm 1.7$ & $6.8 \pm 1.6$ & $0.2 \pm 0.1$ & & $13.2 \pm 2.2$ & & $16.6 \pm 3.4$ \\
\hline & Other zooplankton & & $20.3 \pm 4.1$ & $21.1 \pm 3.6$ & $8.8 \pm 3.9$ & & $18.6 \pm 2.9$ & & $12.4 \pm 1.3$ \\
\hline
\end{tabular}

Table 5. Aethia pusilla. Seasonal changes in $\delta^{13} \mathrm{C}$ values (mean $\pm \mathrm{SE}$ ) in red blood cells of least auklets breeding on St. Paul I. (shelf) and St. George I. (shelf-break), Pribilof Islands, in 2003 to 2005 and 2008 to 2009. r: Pearson correlation coefficient between isotope and day of year; statistically significant relationships $(p<0.05)$ are indicated in bold

\begin{tabular}{|c|c|c|c|c|c|c|}
\hline \multirow[t]{2}{*}{ Year } & \multicolumn{4}{|c|}{$-\delta^{13} \mathrm{C}$} & \multirow{2}{*}{ Slope } & \multirow{2}{*}{ r $(95 \% \mathrm{CI})$} \\
\hline & 2 Jun to 21 Jun & $28 \mathrm{Jun}$ to $14 \mathrm{Jul}$ & $19 \mathrm{Jul}$ to $30 \mathrm{Jul}$ & 2 Aug to 12 Aug & & \\
\hline \multicolumn{7}{|l|}{ St. Paul } \\
\hline 2003 & $-19.5 \pm 0.11$ & $-18.0 \pm 0.13$ & & & 0.042 & $0.85(0.73,0.93)$ \\
\hline 2004 & $-18.9 \pm 0.09$ & $-19.2 \pm 0.07$ & $-19.3 \pm 0.03$ & & -0.008 & $-0.39(-0.12,-0.61)$ \\
\hline 2005 & $-19.4 \pm 0.20$ & $-18.3 \pm 0.11$ & $-18.5 \pm 0.12$ & & 0.027 & $0.65(0.29,0.85)$ \\
\hline 2008 & & $-17.5 \pm 0.12$ & $-17.8 \pm 0.12$ & $-18.5 \pm 0.05$ & -0.024 & $-0.83(-0.93,-0.62)$ \\
\hline 2009 & & $-17.6 \pm 0.07$ & $-18.0 \pm 0.12$ & $-19.2 \pm 0.07$ & -0.058 & $-0.91(-0.95,-0.81)$ \\
\hline & 2 Jun to 21 Jun & $3 \mathrm{Jul}$ & $13 \mathrm{Jul}$ to $14 \mathrm{Jul}$ & 2 Aug to 12 Aug & & \\
\hline \multicolumn{7}{|l|}{ St. George } \\
\hline 2003 & & $-21.3 \pm 0.10$ & $-21.3 \pm 0.08$ & $-19.3 \pm 0.07$ & 0.055 & $0.92(0.81,0.97)$ \\
\hline 2004 & $-20.1 \pm 0.05$ & $-19.5 \pm 0.11$ & $-19.8 \pm 0.04$ & & 0.007 & $0.39(-0.05,0.71)$ \\
\hline 2005 & $-20.4 \pm 0.08$ & $-19.3 \pm 0.05$ & $-19.5 \pm 0.08$ & & 0.022 & $0.82(0.60,0.92)$ \\
\hline 2008 & & $-19.7 \pm 0.09$ & $-20.0 \pm 0.04$ & $-20.0 \pm 0.08$ & -0.010 & $-0.59(-0.82,-0.20)$ \\
\hline 2009 & & $-18.3 \pm 0.13$ & $-18.6 \pm 0.07$ & $-19.2 \pm 0.07$ & -0.031 & $-0.82(-0.91,-0.65)$ \\
\hline
\end{tabular}

Seasonal dynamics of $\delta^{13} \mathrm{C}$ were similar between auklets on the 2 islands in 2003 and 2005 (Island $x$ Date interaction term: 2003: $F_{1,51}=3.11, \mathrm{p}=0.084$; 2005: $F_{1,37}=0.33, \mathrm{p}=0.567$ ) but not in 2004, 2008 and 2009 (Island $\times$ Date interaction term: 2004: $F_{1,64}=$ 9.15, $\mathrm{p}=0.004 ; 2008: F_{1,37}=7.16, \mathrm{p}=0.011 ; 2009$ : $\left.F_{1,56}=17.27, \mathrm{p}<0.001\right)$. However, the relationships between $\delta^{13} \mathrm{C}$ were similar between the islands and were strongly influenced by summer PDO and IRI (Table 5, Fig. 4). During warm years (positive PDO and early ice retreat), $\delta^{13} \mathrm{C}$ values generally increased or remained stable over the season, while they decreased during the cold years (negative PDO and late ice retreat). 


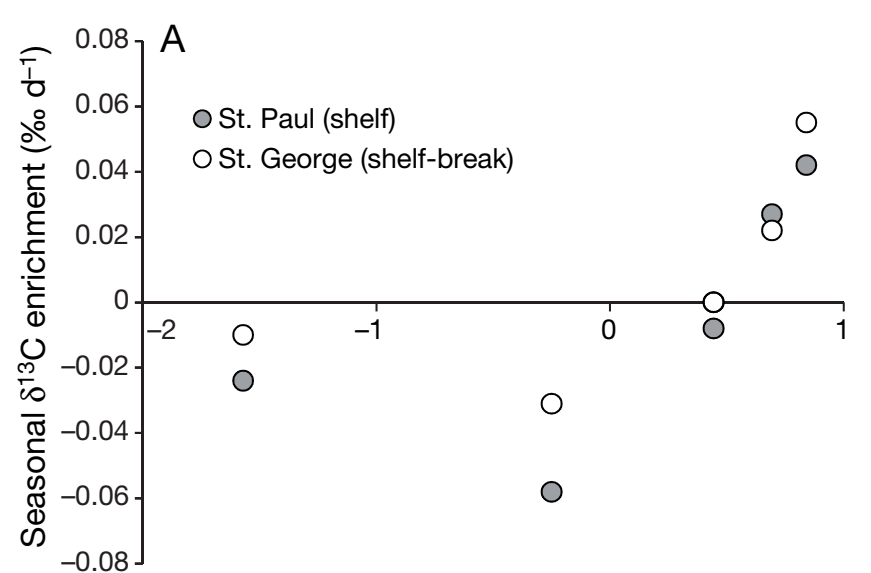

Summer PDO

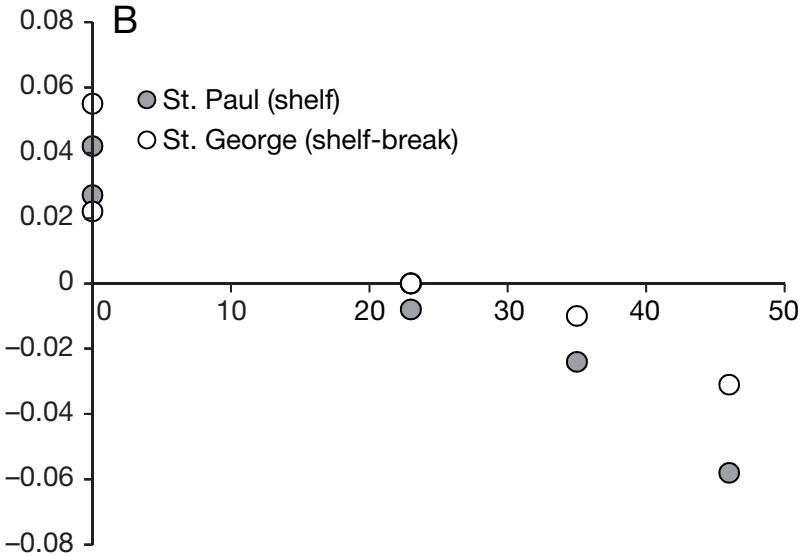

Ice Retreat Index

Fig. 4. Aethia pusilla. Relationship between the summer (A) Pacific Decadal Oscillation (PDO) and (B) Ice Retreat Index and the seasonal changes in $\delta^{13} \mathrm{C}$ values in red blood cells of least auklets breeding on St. Paul I. (shelf) and St. George I. (shelfbreak), Pribilof Islands, in 2003 to 2005 and 2008 to 2009. Seasonal changes in the $\delta^{13} \mathrm{C}$ values are indicated by the slope (seasonal isotope enrichment) of the regression between the $\delta^{13} \mathrm{C}$ and sampling date for each island and for each year

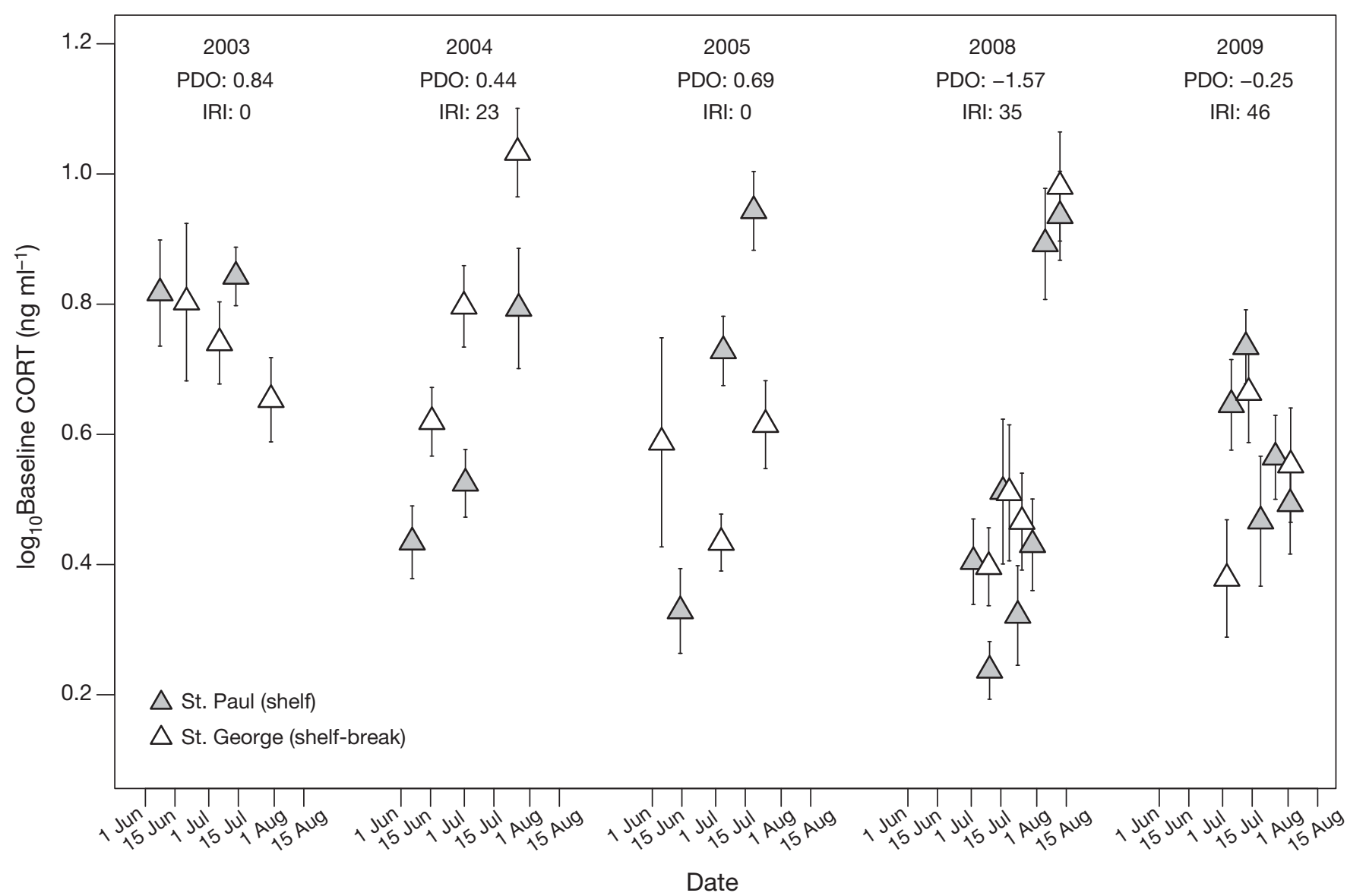

Fig. 5. Aethia pusilla. Seasonal changes of baseline corticosterone levels (CORT; mean \pm SE) in the blood plasma of least auklets breeding on St. Paul I. (shelf) and St. George I. (shelf-break), Pribilof Islands, in 2003 to 2005 and 2008 to 2009 . The summer Pacific Decadal Oscillation (PDO) and Ice Retreat Index (IRI) values are shown for each year. Seasonal dynamics of corticosterone varied among years, but was similar between the islands in 2003, 2004 and 2008 
Corticosterone levels increased during the breeding season, with the exception of 2003 and 2009. Seasonal dynamics in baseline levels of corticosterone were similar between auklets on the 2 islands in 2003, 2004 and 2008 (Island $\times$ Date interaction term: 2003: $F_{1,70}=1.07, \mathrm{p}=0.304 ; 2004: F_{1,83}=1.81, \mathrm{p}=$ 0.182; 2008: $F_{1,102}=0.14, \mathrm{p}=0.710 ;$ Fig. 5$)$ but not in 2005 and 2009 (Island $\times$ Date interaction term: 2005: $F_{1,73}=14.39, \mathrm{p}<0.001 ; 2009: F_{1,78}=4.16, \mathrm{p}=0.045$; Fig. 5).

\section{DISCUSSION}

\section{Inter-annual climate variability affects temporal dynamics in food availability}

In this study we used a 2-pronged approach to examine the effects of climate variability on the food availability to planktivores in one of the most productive marine areas, the Green Belt in the southeastern Bering Sea. Diet compositions and stable-isotope signatures of auklets' red blood cells indicated differences in zooplankton prey and foraging areas between birds breeding on St. Paul and St. George Islands. Despite these differences, inter-annual dynamics of corticosterone levels in the blood plasma were similar between the islands. Similar to longterm observations in other seabird species (Buck et al. 2007, Kitaysky et al. 2007, 2010, Shultz \& Kitaysky 2008, we did not observe a consistent pattern (increase or decrease) in corticosterone levels between incubation and chick-rearing. Thus, variations in corticosterone levels in least auklets do not reflect changes of the energetic demands of the birds between reproductive stages, but rather reflect changes in food availability.

As we predicted, we found that food availability (as reflected in corticosterone values) was lower during the warm (positive PDO) compared to cold (negative PDO) years on both St. Paul I. and St. George I. However, the timing of ice-retreat only had a large effect on auklets breeding on St. Paul I., with higher food availability (as reflected in corticosterone values) during years with late ice retreat. This inconsistency of auklet responses to the timing of ice retreat between the islands might be explained by the fact that summer PDO and IRI were changing in parallel during all years except from 2004. Birds on St. George I. had their highest levels of corticosterone levels in 2004, which had a late timing of ice retreat but later developed into a warm year with a high summer PDO. This illustrates that for a cold regime to support high levels of food resources to planktivores, both a late ice retreat and sustained cold water temperatures throughout the summer are needed.

The observed difference in corticosterone levels between cold and warm regimes is likely to affect the birds differently. High levels of nutritional stress reduce reproductive success and survival of adult seabirds, which might have immediate impact on population dynamics (Buck et al. 2007, Kitaysky et al. 2007, 2010). Disappearance of lipid-rich oceanic copepods from the diets can also impose severe nutritional limitations on growing auklet chicks (Springer et al. 1986, Roby 1991, Gall et al. 2006), which could increase their post-fledging mortality (Kitaysky et al. 2003, 2006). Thus, mediated by the physiological effects of nutritional stress, a warming climate is likely to have a negative impact on planktivores in the productive Green Belt area of the southeastern Bering Sea, as observed in other areas of the North Pacific (Kitaysky \& Golubova 2000, Sydeman et al. 2006, Hipfner 2008, Bond et al. 2011).

\section{Spatial and temporal heterogeneity of zooplankton communities}

The differences in diet composition and use of foraging areas (indicated in carbon stable isotope signatures of their blood) between least auklets breeding on St. Paul I. and St. George I. supported our predictions and reflected the proximity of the respective colony to the continental shelf break. Our findings on the effects of climate on diet composition were also in line with our predictions. During the warm years, 2003 to 2005, birds breeding on St. Paul I. (shelf area) switched diets from lipid-rich copepods to zooplankton with lower lipid content (Springer et al. 2007), whereas oceanic copepods dominated the diets of birds breeding on St. George I. (shelf-break area). In contrast, Neocalanus copepods dominated the diets on both islands during cold years. As we expected, red blood cells of birds breeding on St. Paul I. (situated in the continental shelf region) were enriched in $\delta^{13} \mathrm{C}$ values compared to birds breeding on St. George I. (shelf-break) and on the Aleutian Islands (ocean basin) (Fig. 2). The enriched $\delta^{13} \mathrm{C}$ values observed in birds breeding on St. Paul I. reflect a diet originating in the shelf ecosystem (Hobson et al. 1994, Schell et al. 1998) and hereafter will be referred to as $\delta^{13} \mathrm{C}$ shelf signatures.

Contrary to our predictions, the inter-island difference in $\delta^{13} \mathrm{C}$ signatures was not more pronounced during warm years, and we did not find a clear inter- 
annual effect of climate on $\delta^{13} \mathrm{C}$. However, interestingly we found that the $\delta^{13} \mathrm{C}$ shelf signatures were still evident in the red blood cells of birds breeding on St. Paul I. in 2008 and 2009 when oceanic Neocalanus copepods dominated their diets. The mismatch between oceanic Neocalanus copepods in least auklet chick meals and the $\delta^{13} \mathrm{C}$ shelf signature in the red blood cells of adults could have resulted from a change in the location, and therefore isotope signatures, of Neocalanus copepods. Oceanic Neocalanus copepods, though originating in the ocean basin, would have obtained enriched $\delta^{13} \mathrm{C}$ signatures typical of the shelf ecosystem if they relied on the shelf foodweb for foraging (Schell et al. 1998). The $\delta^{13} \mathrm{C}$ signatures of Neocalanus copepods collected in different regions of the southeastern Bering Sea in mid-July of 2008 suggest that this is likely. For example, the $\delta^{13} \mathrm{C}$ signatures of Neocalanus copepods sampled in close proximity to St. Paul I. $\left(\delta^{13} \mathrm{C}=\right.$ $-18.16 \%$ and $-18.30 \%$ for $N$. cristatus and N. flemingerei, respectively) were higher compared to Neocalanus spp. collected in shelf-break areas $\left(\delta^{13} \mathrm{C}=\right.$ $-20.33 \%$ and $-21.16 \%$ for $N$. cristatus and $N$. flemingerei, respectively), which resembled isotope signatures of open-ocean foraging auklets (Fig. 1) (A. Pinchuk unpubl. data). Least auklets were observed to be foraging in close proximity to the respective islands in 2008 (K. Kuletz pers. comm.) and in previous years (Obst et al. 1995). Alternatively, the mismatch between oceanic Neocalanus copepods in least auklet chick meals and the enriched $\delta^{13} \mathrm{C}$ signature in the red blood cells of adults could reflect a difference between adult and chick diets. For example, common guillemots Uria aalge that carry a single prey item to their chicks have been observed to feed on low quality prey themselves while feeding their chick with high quality prey (Wilson et al. 2004). However, Bédard (1969) found no differences between adult and chick diets in the least auklet. Therefore, it seems more likely that oceanic copepods near St. Paul I. were part of the shelf food web, and during cold years they obtained stronger shelf $\delta^{13} \mathrm{C}$ signatures by having a longer retention time on the shelf, either by an earlier advection on the shelf or by having a longer lifespan on the shelf compared to warm years.

\section{Possible mechanisms driving temporal dynamics in food availability}

Our results on auklet responses to climate variability in the Green Belt are in line with the $\mathrm{OCH}_{\text {; }}$ during warm years zooplankton availability to planktivorous predators is lower compared to cold years. The $\mathrm{OCH}$ predicts that during cold years with late ice retreat, an early ice-associated phytoplankton bloom sustains a high abundance of mesozooplankton, the food source of planktivorous predators. In contrast, during warm years with early ice retreat, a delayed open-water phytoplankton bloom is not sufficient to sustain a high biomass of meso-zooplankton and, in turn, determines a low availability of prey to planktivorous predators (Hunt et al. 2008, 2011, Coyle et al. 2011). However, these predictions of the $\mathrm{OCH}$ are specific for mesozooplankton species originating in the middle shelf domain (such as Calanus marshallae), while for the least auklets and most likely other planktivorous predators in the Green Belt, the summer biomass of oceanic Neocalanus copepods advected onto the continental shelf is probably more critical. Additionally, the $\mathrm{OCH}$ predicts enhanced phytoplankton production on the shelf during cold years and the possibility of a secondary bloom when mixing is sufficient; whereas during warm years, higher water temperatures increase stratification of the water column and prevent any mixing, leading to nutrient depletion (Hunt et al. 2002, 2008). During cold years, the Neocalanus copepods advected on the shelf are well supported by an enhanced productivity of the shelf ecosystem; whereas during warm years, the Neocalanus copepods advected on the shelf are probably severely food-limited and may experience high mortality due to starvation (Coyle et al. 2008). Thus Neocalanus copepods are dependent on the shelf productivity. Nevertheless, the proportion of large oceanic copepods in least auklet diets was only positively related to the timing of sea ice retreat and negatively related to the summer PDO for birds breeding on St. Paul I., and not on St. George I. Although this difference between colonies is to be expected, with zooplankton on the shelf being more reliant on the processes occurring on the shelf compared to zooplankton at the shelfbreak, the effects of summer PDO on food availability (as reflected in corticosterone levels) were similar between St. Paul I. and St. George I. Thus, although the $\mathrm{OCH}$ is still applicable for predicting the effects of climate variability on the Green Belt ecosystem, the timing of winter ice retreat and summer sea surface temperatures alone are insufficient to explain changes of prey availability to planktivorous predators in the region.

Two scenarios have been proposed to affect copepod abundance during 'warm' and 'cold' years: (1) 
In the North Pacific, increased sea-surface temperatures are associated with earlier ontogenetic migration of Neocalanus plumchrus to depth and/or increased mortality of later cohorts (Mackas et al. 1998, 2007), making them unavailable to planktivorous seabirds (Hipfner 2008). For auklets, which rely on a predictable copepod biomass peak for feeding their young, timing of the different stages of the Neocalanus life cycle determines the temporal overlap between copepod biomass peak and the energetic demands of the breeding season (Hipfner 2008). A recent shift towards an earlier occurrence of CV-copepodite stages in Neocalanus spp. was also observed in the Bering Sea shelf in the late 1990s, as compared to the early 1980s (Napp et al. 2002), and Coyle et al. (2008) suggested that increased mortality due to food limitation may have caused a decline in the abundance of shelf copepods on the shelf during warm years. However, the disappearance of Neocalanus copepods from the diets on St. Paul I. during the warm years of 2003 to 2005 cannot be fully explained by their early ontogenetic migration or increased mortality during warm years. Neocalanus were still available to auklets on St. George I. and yet birds on both colonies experienced similar high stress levels during these warm years. Thus, changes in the timing of Neocalanus life cycle and increased Neocalanus mortality cannot be the only mechanism affecting availability of food to planktivores in the Green Belt.

(2) In the Pribilof Domain, changes in the physical oceanographic conditions might affect Neocalanus copepod distribution, displacing them outside the foraging realm of least auklets (Springer et al. 2007). In the warm year of 2004, food availability declined on St. Paul I. in response to the movement of copepod-depleted shelf water into the Pribilof Domain (Coyle et al. 2008, Hunt et al. 2008, Stabeno et al. 2008), and a concurrent food shortage was observed in birds on St. George I. (BenowitzFredericks et al. 2008). These observations suggest a parallel response of auklets breeding on both islands to a major change in physical oceanography that affected the entire Pribilof Domain. The arrival of copepod- depleted shelf waters into the Pribilof Domain probably occurs on a regular basis during warm years, as evidenced in the seasonal enrichment of birds' $\delta^{13} \mathrm{C}$ signatures in 2003 and 2005 indicative of foraging in shelf waters. In contrast, during the cold years of 2008 to $2009, \delta^{13} \mathrm{C}$ values gradually declined during the season, suggesting that there was a continuous influx of oceanic water into the Pribilof Domain. It has been suggested that the direction of major currents may change between warm and cold years on the middle shelf domain, however, little is known about how it would affect inflow of oceanic water masses into the Pribilof Domain and other parts of the Green Belt (Stabeno et al. 2008). Our results suggest that the inflow of oceanic water masses is stronger during cold years and that during warm years the inflow might be prevented by the expansion of shelf water increasing the strength of the front between oceanic and shelf water masses. Thus, besides the effects of climate on phytoplankton productivity on the shelf and its subsequent effect on Neocalanus mortality, the dynamic interactions of the oceanic and shelf water masses on the continental shelf are likely to be the main factors governing availability of zooplankton to planktivores in the Green Belt.
WARM REGIME

(early winter ice retreat \& high water temperatures)

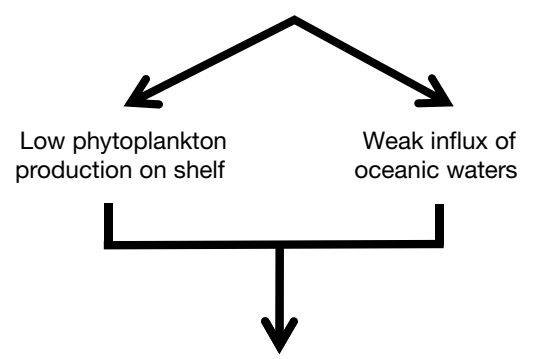

Low abundance \& short retention of Neocalanus copepods

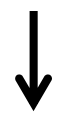

Least auklets:

Low proportion of Neocalanus in diets \& high nutritional stress

Negative effect on planktivorous predators in the Green Belt
COLD REGIME

(late winter ice retreat \& low water temperatures)

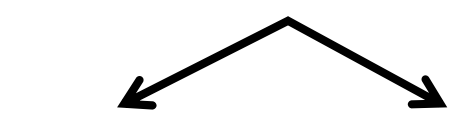

High phytoplankton production on shelf

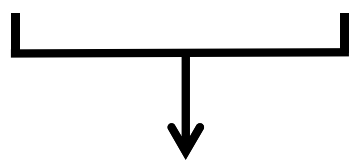

High abundance \& long retention of Neocalanus copepods

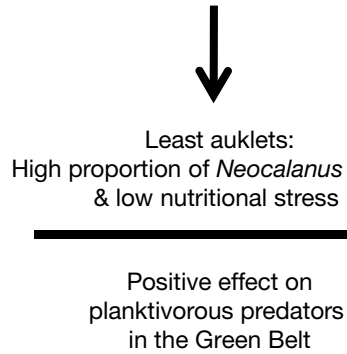

Fig. 6. Flow diagram showing our predictions about how climate affects planktivorous predators in the Green Belt of the Bering Sea. Climate-induced changes in physical forcing will negatively affect planktivores by altering the availability of their main food source, Neocalanus copepods, during warm years (see 'Conclusions' for details) 


\section{CONCLUSIONS}

The present study adds to the growing understanding of seabird responses to climate variability and change. We can use our data to generate basic predictions about the effects of warming climate on planktivorous predators in the Green Belt of the Bering Sea through bottom-up processes, which might be applicable to other continental shelf regions with seasonal ice cover (Fig. 6). During a warm regime the phytoplankton bloom on the shelf is limited, and the influx of oceanic water onto the shelf is weak. This results in low abundance and short retention time of oceanic Neocalanus copepods on the shelf. Decreasing availability of Neocalanus copepods increases nutritional stress in planktivorous predators and will thus negatively affect them. In contrast, during cold regimes the phytoplankton bloom on the shelf is strong, and retention time of Neocalanus copepods on the shelf is long. High abundance of Neocalanus copepods results in low nutritional stress levels of planktivorous predators and more favorable conditions. Testing this hypothesis will require an integrated study of seasonal water movements in the region while simultaneously monitoring changes in zooplankton communities and food availability of planktivorous predators.

Acknowledgements. We thank S. Baker, A. Banks, J. Citta, T. Dempsey, H. Douglas, B. Drummond, C. Hovnanian, S. Iverson, J. Klima, C. Polli, A. Springer, C. Thomson, T. Vergoz, S. Wang and S. Youngren for their great work in the field. We thank E. Kitaiskaia for her excellent hormone analyses; K. Turco and C. Stark for identification of zooplankton; N. Haubenstock and T. Howe from the Stable Isotope facilities in Fairbanks for conducting SIA. Thanks to R. Parades for help with Fig. 1. G. Hunt, J. Schultner and 3 anonymous reviewers provided us with helpful comments on previous drafts of this manuscript. This study was conducted under the University of Alaska IACUC protocols and all required federal and state permits. This project was supported by NPRB 320 and B67 grants to A.S.K., and by grants from the HSP-fonds, AUV-fonds and Jo-Kolk Studiefonds to I.D. This paper is NPRB Publication \#305 and BEST-BSIERP Bering Sea Project Publication \#26

\section{LITERATURE CITED}

Baier CT, Napp JM (2003) Climate-induced variability in Calanus marshallae populations. J Plankton Res 25: $771-782$

Bédard J (1969) Feeding of the least, crested and parakeet auklets around St. Lawrence Island, Alaska. Can J Zool 47:1025-1050

> Benowitz-Fredericks ZM, Shultz MT, Kitaysky AS (2008) Stress hormones suggest opposite trends of food availability for planktivorous and piscivorous seabirds in 2 years. Deep-Sea Res II 55:1868-1876

> Bond AL, Jones IL, Sydeman WJ, Major HL, Minobe S,
Williams JC, Byrd GV (2011) Reproductive success of planktivorous seabirds in the North Pacific is related to ocean climate on decadal scales. Mar Ecol Prog Ser 424: 205-218

> Buck CL, O'Reilly KA, Kildaw SD (2007) Interannual variability of black-legged kittiwake productivity is reflected in baseline plasma corticosterone. Gen Comp Endocrinol 150:430-436

> Carleton SA, del Rio CM (2005) The effect of cold-induced increased metabolic rate on the rate of ${ }^{13} \mathrm{C}$ and ${ }^{15} \mathrm{~N}$ incorporation in house sparrows (Passer domesticus). Oecologia 144:226-232

Coyle KO, Pinchuk AI, Eisner LB, Napp JM (2008) Zooplankton species composition, abundance and biomass on the eastern Bering Sea shelf during summer: the potential role of water-column stability and nutrients in structuring the zooplankton community. Deep-Sea Res II 55:1775-1791

Coyle KO, Eisner LB, Mueter FJ, Pinchuk AI and others (2011) Climate change in the southeastern Bering Sea: impacts on pollock stocks and implications for the oscillating control hypothesis. Fish Oceanogr 20:139-156

> Doody LM, Wilhelm SI, McKay DW, Walsh CJ, Storey AE (2008) The effects of variable foraging conditions on common murre (Uria aalge) corticosterone concentrations and parental provisioning. Horm Behav 53:140-148

Furness RW, Camphuysen CJ (1997) Seabirds as monitors of the marine environment. ICES J Mar Sci 54:726-737

Gall AE, Roby DD, Irons DB, Rose IC (2006) Differential response in chick survival to diet in least and crested auklets. Mar Ecol Prog Ser 308:279-291

Hipfner JM (2008) Matches and mismatches: ocean climate, prey phenology and breeding success in a zooplanktivorous seabird. Mar Ecol Prog Ser 368:295-304

Hobson KA, Clark RG (1992) Assessing avian diets using stable isotopes. I: Turnover of ${ }^{13} \mathrm{C}$ in tissues. Condor 94: 181-188

Hobson KA, Clark RG (1993) Turnover of ${ }^{13} \mathrm{C}$ in cellular and plasma fractions of blood: implications for nondestructive sampling in avian dietary studies. Auk 110:638-641

> Hobson KA, Piatt JF, Pitocchelli J (1994) Using stable isotopes to determine seabird trophic relationships. J Anim Ecol 63:786-798

> Hunt GL Jr, Stabeno P, Walters G, Sinclair E, Brodeur RD, Napp JM, Bond NA (2002) Climate change and control of the southeastern Bering Sea pelagic ecosystem. DeepSea Res II 49:5821-5853

> Hunt GL Jr, Stabeno PJ, Strom S, Napp JM (2008) Patterns of spatial and temporal variation in the marine ecosystem of the southeastern Bering Sea, with special reference to the Pribilof Domain. Deep-Sea Res II 55:1919-1944

> Hunt GL Jr, Coyle KO, Eisner LB, Farley EV and others (2011) Climate impacts on eastern Bering Sea food webs: a synthesis of new data and an assessment of the Oscillating Control Hypothesis. ICES J Mar Sci 68:1230-1243

- Irons DB, Anker-Nilssen T, Gaston AJ, Byrd GV and others (2008) Fluctuations in circumpolar seabird populations linked to climate oscillations. Glob Change Biol 14: 1455-1463

Ji R, Edwards M, Mackas DL, Runge JA, Thomas AC (2010) Marine plankton phenology and life history in a changing climate: current research and future directions. J Plankton Res 32:1355-1368

Jones IL (1993) Least auklet (Aethia pusilla). In: Poole A, Gill F (eds) The Birds of North America, Vol 69. The Academy of Natural Sciences, Philadelphia, PA, and The 
American Ornithologists' Union, Washington, DC

Kitaysky AS, Golubova EG (2000) Climate change causes contrasting trends in reproductive performance of planktivorous and piscivorous alcids. J Anim Ecol 69:248-262

> Kitaysky AS, Piatt JF, Wingfield JC, Romano M (1999a) The adrenocortical stress-response of black-legged kittiwake chicks in relation to dietary restrictions. J Comp Physiol B 169:303-310

Kitaysky AS, Wingfield JC, Piatt JF (1999b) Dynamics of food availability, body condition and physiological stress response in breeding black-legged kittiwakes. Funct Ecol 13:577-584

Kitaysky AS, Kitaiskaia EV, Wingfield JC, Piatt JF (2001) Dietary restriction causes chronic elevation of corticosterone and enhances stress response in red-legged kittiwake chicks. J Comp Physiol B 171:701-709

Kitaysky AS, Kitaiskaia E, Piatt J, Wingfield JC (2003) Benefits and costs of increased levels of corticosterone in seabird chicks. Horm Behav 43:140-149

Kitaysky AS, Kitaiskaia EV, Piatt JF, Wingfield JC (2006) A mechanistic link between chick diet and decline in seabirds? Proc Biol Sci 273:445-450

Kitaysky AS, Piatt JF, Wingfield JC (2007) Stress hormones link food availability and population processes in seabirds. Mar Ecol Prog Ser 352:245-258

Kitaysky AS, Piatt JF, Hatch SA, Kitaiskaia EV, BenowitzFredericks ZM, Shultz MT, Wingfield JC (2010) Food availability and population processes: severity of nutritional stress during reproduction predicts survival of long-lived seabirds. Funct Ecol 24:625-637

Konyukhov N (2008) Resighting of banded least auklets Aethia pusilla on St. George Island, Pribilof Islands, in 2008. US Fish and Wildlife Service Rep AMNWR 08/10, Homer, AK

Mackas DL, Goldblatt R, Lewis AG (1998) Interdecadal variation in developmental timing if Neocalanus plumchrus populations at Ocean Station P in the subarctic North Pacific. Can J Fish Aquat Sci 55:1878-1893

Mackas DL, Batten S, Trudel M (2007) Effects on zooplankton of a warmer ocean: recent evidence from the Northeast Pacific. Prog Oceanogr 75:223-252

Mantua NJ, Hare SR, Zhang Y, Wallace JM, Francis RC (1997) A Pacific interdecadal climate oscillation with impacts on salmon production. Bull Am Meteorol Soc 78: 1069-1079

- Napp JM, Baier CT, Brodeur RD, Coyle KO, Shiga N, Mier K (2002) Interannual and decadal variability in zooplankton communities of the southeast Bering Sea shelf. DeepSea Res II 49:5991-6008

Obst BS, Russell RW, Hunt GL Jr, Eppley ZA, Harrison NM (1995) Foraging radii and energetics of least auklets (Aethia pusilla) breeding on three Bering Sea islands. Physiol Zool 68:647-672

Piatt JF, Sydeman WJ, Wiese F (2007) Introduction: Seabirds as indicators of marine ecosystems. Mar Ecol Prog Ser 352:199-204

Quillfeldt P, McGill RAR, Furness RW (2005) Diet and foraging areas of Southern Ocean seabirds and their prey inferred from stable isotopes: review and case study of Wilson's storm-petrel. Mar Ecol Prog Ser 295:295-304

Roby DD (1991) Diet and postnatal energetics in convergent taxa of plankton-feeding seabirds. Auk 108:131-146

Roby DD, Brink KL (1986) Breeding biology of least auklets on the Pribilof Islands, Alaska. Condor 88:336-346

Romero LM, Reed JM (2005) Collecting baseline cortico- sterone samples in the field: is under 3 min good enough? Comp Biochem Physiol A Mol Int Physiol 140:73-79

Sapolsky RM, Romero LM, Munck AU (2000) How do glucocorticoids influence stress responses? Integrating permissive, suppressive, stimulatory, and preparative actions. Endocr Rev 21:55-89

Schell DM, Barnett BA, Vinette KA (1998) Carbon and nitrogen isotope ratios in zooplankton of the Bering, Chukchi and Beaufort seas. Mar Ecol Prog Ser 162:11-23

Shultz MT, Kitaysky AS (2008) Spatial and temporal dynamics of corticosterone and corticosterone binding globulin are driven by environmental heterogeneity. Gen Comp Endocrinol 155:717-728

Shultz MT, Piatt JF, Harding AMA, Kettle AB, Van Pelt TI (2009) Timing of breeding and reproductive performance in murres and kittiwakes reflect mismatched seasonal prey dynamics. Mar Ecol Prog Ser 393:247-258

Smith SL, Henrichs SM, Rho T (2002) Stable C and N isotopic composition of sinking particles and zooplankton over the southeastern Bering Sea shelf. Deep-Sea Res II 49:6031-6050

> Springer AM, Roseneau DG (1985) Copepod-based food webs: auklets and oceanography in the Bering Sea. Mar Ecol Prog Ser 21:229-237

Springer AM, Roseneau DG, Lloyd DS, McRoy CP, Murphy EC (1986) Seabird responses to fluctuating prey availability in the eastern Bering Sea. Mar Ecol Prog Ser 32:1-12

> Springer AM, McRoy CP, Flint MV (1996) The Bering Sea Green Belt: shelf-edge processes and ecosystem production. Fish Oceanogr 5:205-223

Springer AM, Byrd GV, Iverson SJ (2007) Hot oceanography: planktivorous seabirds reveal ecosystem responses to warming of the Bering Sea. Mar Ecol Prog Ser 352: 289-297

Stabeno PJ, Kachel N, Mordy C, Righi D, Salo S (2008) An examination of the physical variability around the Pribilof Islands in 2004. Deep-Sea Res II 55:1701-1716

> Sydeman WJ, Bradley RW, Warzybok P, Abraham CL and others (2006) Planktivorous auklet Ptychoramphus aleuticus responses to ocean climate, 2005: Unusual atmospheric blocking? Geophys Res Lett 33:L22S09, doi: 10. 1029/2006GL026736

> Welcker J, Harding AMA, Kitaysky AS, Speakman JR, Gabrielsen GW (2009) Daily energy expenditure increases in response to low nutritional stress in an Arcticbreeding seabird with no effect on mortality. Funct Ecol 23:1081-1090

> Williams CT, Buck CL, Sears J, Kitaysky AS (2007) Effects of nutritional restriction on nitrogen and carbon stable isotopes in growing seabirds. Oecologia 153:11-18

Wilson LJ, Daunt F, Wanless S (2004) Self-feeding and chick provisioning diet differ in the common guillemot Uria aalge. Ardea 92:197-207

Wingfield JC, Farner DC (1975) The determination of five steroids in avian plasma by radioimmunoassay and competitive protein binding. Steroids 26:311-321

Wingfield JC, Kitaysky AS (2002) Endocrine responses to unpredictable environmental events: Stress or anti-stress hormones? Integr Comp Biol 42:600-609

> Wingfield JC, Hegner RE, Lewis D (1991) Circulating levels of luteinizing hormone and steroid hormones in relation to social status and cooperatively breeding white-browed sparrow weaver, Plocepasser mahali. J Zool 225:43-58

Zar JH (1999) Biostatistical analysis. Prentice-Hall, Upper Saddle River, NJ 